Public parks and urban development during the nineteenth and twentieth centuries in Nottingham

John Beckett

Department of History, University of Nottingham, Nottingham, NG7 2RD, UK

John.Beckett@nottingham.ac.uk

John Beckett is Professor of English Regional History, University of Nottingham 


\title{
Public parks and urban development during the nineteenth and twentieth centuries in Nottingham
}

\begin{abstract}
It is well known that Nottingham was one of the most densely built and overcrowded towns in Victorian England. Following the enclosure, 1845-65, green spaces, including public parks, had to be provided in the new suburbs. This article looks at the creation of parks in the nineteenth and twentieth centuries to show how a combination of government policies, local authority commitment to providing open spaces and recreation grounds, and philanthropic involvement, led to the post-1845 town and its newly created suburbs having numerous accessible green spaces. This provision has, in turn, impacted on how the modern city has evolved, and the article suggests that this is important for our understanding of urban development more generally. The paper notes the impact of more recent development where large swathes of working class housing, with few or no green spaces, has been swept away and replaced by a significantly greener environment.
\end{abstract}

Keywords: Nottingham; green spaces; Arboretum; Forest; parks; recreation grounds

The creation of public parks, recreation grounds and green spaces in the newly industrialising British towns of the nineteenth and twentieth centuries was a key part of urban policy making from the 1830s onwards. Perhaps surprisingly in these circumstances, the study of parks, as opposed to the study of individual parks, has not attracted as much attention as might have been anticipated. ${ }^{1}$ The key text is still Hazel Conway's People's Parks, published nearly thirty years ago, ${ }^{2}$ while the most recent

\footnotetext{
${ }^{1}$ Roy Rosenzweig, 'The Parks and the People: Social History and Urban parks', Journal of Social History, XVIII (1984), 289-95.

${ }^{2}$ Hazel Conway, People's Parks: the design and development of Victorian Parks in Britain (Cambridge: Cambridge University Press, 1991).
} 
general study is by a journalist rather than a historian. ${ }^{3}$ There are just a handful of references to parks in the three volume Cambridge Urban History, published in $2000 .{ }^{4}$ The output of relevant literature has increased subsequently as historians and garden experts have become more interested in both the history and the maintenance of urban green spaces. ${ }^{5}$ This article raises questions about the creation of parks between the 1830s and the inter-war years. It does so primarily in the context of Nottingham, and it follows from earlier work on the creation of parks in the town in the wake of its 1845 enclosure act. ${ }^{6}$ Part one of the paper concentrates on the creation of public parks in

${ }^{3}$ Travis Elborough, A Walk in the Park: the life and times of a people's institution (London: Jonathan Cape, 2016).

${ }^{4}$ D.M. Palliser, ed., The Cambridge Urban History of Britain volume I 600-1540 (Cambridge: Cambridge University Press, 2000); Peter Clark, ed., The Cambridge Urban History of Britain volume 2, 1540-1840 (Cambridge: Cambridge University Press, 2000); Martin Daunton, ed., The Cambridge Urban History of Britain volume 3, 1840-1950 (Cambridge: Cambridge University Press, 2000).

${ }^{5}$ Carole O'Reilly, 'From "the people" to "the citizen": the emergence of the Edwardian municipal park in Manchester 1902 - 1912', Urban History 40 (1) (2013), 136-55; Katy Layton-Jones and Robert Lee, Places of Health and Amusement: Liverpool's historic parks and gardens (Swindon, English Heritage, 2008); Katy Layton-Jones, History of Public Park Funding and Management (Historic England, 2016), report 20/2016; Dennis Hardy, “"Freedom not regimentation": Liberalism, garden cities and early town planning', Journal of Liberal History 52 (2006), 20-26; Catharine Ward Thompson, 'Urban open space in the 21 st century', Landscape and Urban Planning 60 (2) (2002), 59-72.

${ }^{6}$ John Beckett and Ken Brand, 'Enclosure, Improvement and the Rise of "New Nottingham”, 1845-67', Transactions of the Thoroton Society, 98 (1994), 92-111; John Beckett, Paul 
Nottingham between the 1830s and the First World War, and part two at the interwar years when parks were created in conjunction with house building programmes. Part three widens the argument to look at park creation in towns and cities elsewhere in the Midlands.

\section{Victorian Parks}

Until the 1830s neither central government nor local authorities showed a great deal of interest in public open spaces, largely because access to space beyond the urban core was relatively straightforward. ${ }^{7}$ Botanical gardens survived in some towns, but the entrance fee was usually sufficient to deter all but the better-off. ${ }^{8}$ However, urban growth and, with it, urban sprawl, raised new questions about the distance many people now lived from space which was suitable for public recreation. Where parks were laid out it was often the result of private enterprise. ${ }^{9}$ An early and significant example was

Elliott, Judith Mills and Jonathan Coope, 'The Social World of Nottingham's Green Spaces', East Midlands History and Heritage 5 (2017), 26-9; John Beckett and Paul Elliott, eds., Nottingham's Green Spaces (Derby: Peregrine Press, 2020)

${ }^{7}$ Conway, People's Parks.

${ }^{8}$ Elaine Mitchell, 'Duddeston's “shady walks and arbours”: the provincial pleasure garden in the eighteenth century', in Gardens and Green Spaces in the West Midlands since 1700 ed. by Malcolm Dick and Elaine Mitchell (Hatfield: University of Hertfordshire Press, 2018), pp. 76101; Paul Elliott, 'People’s Parks: Victorian Urban Public Parks in the West Midlands', <https://historywm.com/articles/peoples-parks $>$ [accessed 30 April 2019]

${ }^{9}$ Layton-Jones, Public Park Funding, 13-20 
Joseph Strutt's gift of Derby arboretum, opened in $1840 .{ }^{10}$ The intention among middle class promoters like Strutt was to make available to the working man and his family, within the physical boundaries of the town, the best of the English countryside in terms of trees, plants and shrubs, and peaceful lakes. These were all set within carefully designed spaces often enclosed with wrought iron railings. ${ }^{11}$ Children were to learn about trees, shrubs, the birds in the aviary and the fish in the lake, replicating contemporary concern with rational (improving) recreation. This was reflected as well in the municipal provision of libraries, art galleries, museums and public baths. ${ }^{12}$

Park promoters had numerous motives. Some saw parks as a weapon in local and regional urban competition, or a way of raising the value of new developments to attract investors. Others saw them as purely philanthropic gifts to the community, and yet others were concerned with the social order in industrialising towns and cities. They recognised that this was an investment worth making: Strutt hired John Claudius Loudon, the foremost landscape gardener and horticulturist of his day, to design Derby Arboretum. ${ }^{13}$

Parliament began to take an interest in the question of park provision during the 1830s, initially through the 1833 Select Committee on Public Walks, which suggested that it was important for the working classes to enjoy fresh air on their day of rest

\footnotetext{
${ }^{10}$ Paul A. Elliott, 'The Derby Arboretum (1840): the first specially designed municipal public park in Britain', Midland History, 26 (2001), 144-76.

${ }^{11}$ Ivor H. Seeley, Outdoor recreation and the Urban Environment (London: Macmillan, 1973), p. 124.

${ }^{12}$ Daunton, Cambridge Urban History, pp. 292, 763.

${ }^{13}$ Elliott, 'Derby Arboretum', 144-76.
} 
(Sunday), and that they needed spaces in which they could walk with their families, dressed 'in their best'. ${ }^{14}$ This incentive to be clean and properly clothed would, contemporaries believed, be an inducement to greater productivity in industry. In 1839 the House of Commons accepted that in all future enclosure bills 'provision be made for leaving an open space in the most appropriate situation sufficient for purposes of exercise and recreation of the neighbouring population', with a facility 'for efficient fencing of the allotment'. ${ }^{15}$ This restriction was reaffirmed in the 1845 General Enclosure Act, which restated Parliamentary commitment to setting aside land for exercise and recreation. However, as Hilary Taylor has noted, making space available for public recreation was not the same as creating a park: 'there was as yet, no taste for a national policy of dedicating substantial areas of land to the common good' ${ }^{16}$

Nor is this surprising. The government offered little by way of funding, and the ratepayers were frequently ambivalent about the issue. They tended to view open spaces in towns as providing for the lower social orders who made only a minimal contribution to the rates. Consequently it took time for local authorities to engage with park creation, and it was not until the 1860s that many industrial towns had a recognisable public park

${ }^{14}$ Select Committee on Public Walks, Parliamentary Papers (House of Commons), 1833, XV, $54-5,57$

${ }^{15}$ J.L. Hammond and Barbara Hammond, The Age of the Chartists, 1832-1854: a study of discontent (London: Longmans, Green, 1930), p. 125.

${ }^{16}$ Hilary A. Taylor, 'Urban Public Parks, 1840-1900: design and meaning', Garden History, 23/2 (1995), 201-21 
within their borders. ${ }^{17}$ This growing commitment was aided by the 1871 Public Parks Act, which allowed land to be donated for use as a public park, and with open spaces increasingly being associated with public events and organised sport, the numbers soon increased. Across the country more public parks were opened 1885-1914 than in any other period, many of them in conjunction with the Golden and Diamond Jubilee celebrations for Queen Victoria in 1887 and 1897. In some cases the new park represented the acquisition and municipalisation of commons, heaths, and other preexisting green spaces. Corporations competed to outdo each other in the ornateness of their bandstands, the number of flower beds, and the quality of their toilets. ${ }^{18}$

Nottingham, as a consequence of the terms of its 1845 Enclosure Act, had been obliged to set aside land for green spaces. After much debate in the corporation, the spaces nominated were the Forest, the Arboretum, the promenading walks (Elm, Corporation, Robin Hood, Queens), and two small parks, Victoria and Queen's Walk. ${ }^{19}$ Burial grounds and church yards were considered by the Victorians to be appropriate open spaces for modest recreation, and so the General Cemetery and the Church (Rock)

${ }^{17}$ Seeley, Outdoor Recreation, p. 95; Sheila Metcalf, 'The Idea of a Park: the Select Committee and the First Public Parks', Journal of Regional and Local Studies, 4/1 (1984), 18-30.

${ }^{18}$ Harriett Jordan, 'Public Parks, 1885-1914', Garden History, 22/1 (1994), 85-113. Three were opened in the Yorkshire town of Keighley 1887-93: Lynn Macgill, 'The Emergence of Public Parks in Keighley, West Yorkshire, 1887-93: leisure, pleasure or reform?' Garden History, 35/2 (2007), 146-59; Elborough, A Walk in the Park, pp. 150-1.

${ }^{19}$ Records of the Borough of Nottingham (RBN), IX (Nottingham: Thomas Foreman \& Son, 1955), pp. 85, 93. 
Cemetery, dating from the 1830 s and 1840 s were included in the list of green spaces. ${ }^{20}$ Nottingham became one of the earliest industrialising towns to promote an enclosure act in which the corporation, operating through the Enclosure Commissioners, was required to set aside land for public open spaces. ${ }^{21}$

Initially public parks and walks such as those in Nottingham were designed for rational recreation but this emphasis shifted as concerns grew about the physical fitness of working men. By the 1880s parks were frequently providing facilities for team sports such as football, ${ }^{22}$ and the 1907 Public Health Amendment Act conferred additional powers on local authorities to provide bowling greens, tennis courts, quoit grounds and land for other games, as well as refreshment rooms and bandstands. ${ }^{23}$ Middle class reformers encouraged sports which were played according to enforceable rules and on pitches laid out within designated recreation areas. These included football and cricket pitches, tennis courts, bowling greens, and appropriate space for archery and cycling. ${ }^{24}$

${ }^{20}$ Beckett and Brand, 'Enclosure'; J. Mills, 'The transformation of green space in old and new Nottingham', Transactions of the Thoroton Society, 118 (2014), 93-114; Conway, People's Parks, pp. 208-13, 215.

${ }^{21}$ Beckett and Brand, 'Enclosure'.

${ }^{22}$ Christine Drew and Paul Elliott, 'Victorian Gardening, Horticulture and Arboriculture in the Midlands: John Frederick Wood (1806-65) of Nottingham and the Midland Florist and Suburban Horticulturalist', Transactions of the Thoroton Society, 120 (2016), 121-42.

${ }^{23}$ Jordan, 'Public Parks', 85-113.

${ }^{24}$ Conway, People's Parks; G.W. Enfield, 'The public walks and recreation grounds of Nottingham', Transactions of the National Association for the Promotion of Social Science (1858), 647-8 adds allotments and small gardens to this list, but these are not discussed here. 
Above all, sports gained approval when they were subject to rules, and overseen by respectable middle class organisations such as the Football Association (1863), the Rugby Union Association (1871), the Amateur Athletic Association (1881), and the Lawn Tennis Association (1888). ${ }^{25}$

Between the 1850s and the 1870s Nottingham Corporation was able to rest on its laurels, confident that it had met all the provision requirements in its implementation of the terms of its 1845 Enclosure Act. The physical growth of the town subsequently, as a result of the demand for housing and for industrial premises, re-opened the question. Football teams had to join a waiting list to use the Forest Recreation Ground, and in February 1876 a deputation from the newly built St Ann's Well Road and Woodborough Road districts asked the corporation to sanction a recreation ground in their area. ${ }^{26}$ The result was that the Coppice recreation ground was laid out that year. ${ }^{27}$

The borough extension act of 1877 brought within Nottingham's boundaries the outlying parishes of Bulwell, Basford, Radford, Lenton and Sneinton. ${ }^{28}$ None of these had public parks, and all were too far from the town centre for the existing parks such as the Arboretum and Forest to serve them. New parks were set out in each of these

${ }^{25}$ Richard Tomlinson, Amazing Grace (2016), p. 67, makes the point that W.G. Grace's towering fame as a cricketer was partly because there were few alternatives in terms of sporting stars. Football was still in its infancy, and only 2,000 spectators turned out for the first FA Cup Final in 1872.

${ }^{26}$ Nottingham Daily Express, 29 Feb 1876.

${ }^{27} R B N$ IX, 248, 263, 272.

${ }^{28}$ Geoffrey Oldfield, 'The Nottingham Borough Boundary Extension of 1877', Transactions of the Thoroton Society, 94 (1990), 83-91. 
suburbs. Bulwell lay four miles north-west of the town centre, and was the most rural of the new parishes. The corporation bought 115 acres of Bulwell Forest in 1879, and laid out a golf course in 1887 together with football and cricket pitches. ${ }^{29}$ In 1908 the corporation bought the Bulwell Hall estate for $£ 35,000$. The hall (c.1770) and 250 acres were converted into a public park, while the rest (325 acres) was let to tenants. The public park included a golf course with pavilion, 8 cricket pitches, 8 practice pitches, four football pitches, three hockey pitches, 4 grass tennis courts, and a lake. ${ }^{30}$

Basford lay south of Bulwell, and to the north of the pre-1877 town boundaries. With very little open space available the corporation took the opportunity to buy Charles Cox's 17-acre estate when it was offered to them in 1900. This was the Vernon House estate in Basford for which they paid $£ 11,750$ in December 1900 . The park’s main feature was the lake with swans, ducks and other birds. There were trees and flower beds, a cricket ground with five pitches, a bowling green, and a grass tennis court. Cox had already vacated the house, which was re-used as a pavilion. The corporation converted the pond into a lake, and opened the new facility to the public. It was enlarged in 1937 when further land was made available. ${ }^{31}$

The other three post-1877 parishes were granted rather sparse recreation grounds with simpler landscaping and planting. They were sometimes little more than a grass space with playgrounds and benches. Lenton Recreation Ground (6 acres, 1887)

${ }^{29} R B N$ IX, 266, 272.

${ }^{30}$ R. Mellors, Old Nottingham Suburbs: then and now (Nottingham: Bell, 1914), pp. 217-18; Robert Mellors, The Gardens, Parks and Walks of Nottingham and District (Nottingham: Bell, 1926), p. 80.

${ }^{31}$ RBN IX, 411; Nottingham City Council, Public Parks Report 1938, 1006. 
fulfilled this profile. Robert Mellors, in his book on Nottingham's green spaces, commented of Lenton that it was 'the first district recreation ground formed by the Corporation, and the work was well done. ${ }^{32}$ Radford Recreation Ground (6 acres) opened in 1904. Mellors, who was generally optimistic in his account of Nottingham's green spaces, noted the fitting selection of trees and flowers, and a bowling green. ${ }^{33} \mathrm{~A}$ park for Sneinton was created in 1908 when the City Council agreed to buy land at the junction of Carlton Road and Dakeyne Street, in the grounds of the old asylum. It was just under 9 acres, and was subsequently named King Edward Park ( 9 acres). ${ }^{34}$ On these smaller parks the bowling green and children's play area tended to take precedence over other activities such as football that needed more (pitch) space.

The 1890 Public Health Act regulated boating pools and boats on lakes, and permitted contributions towards privately sponsored public walks and pleasure grounds. Perhaps as a result, a few small green spaces were opened in Nottingham in the years up to 1914 . They included Sycamore Road (3 acres) in 1910, considered by Mellors to be 'the most picturesque' of all the recreation grounds in Nottingham. ${ }^{35}$ Like the Coppice recreation ground it was on land being developed for housing in and around the Mapperley area to the east of the city centre. ${ }^{36}$

${ }^{32}$ Mellors, Gardens, p. 78; S. Zaleski, 'On the Rec.: the Story of Lenton Recreation Ground', Lenton Times, 23 (2005), 14-18.

${ }^{33}$ Mellors, Gardens, p. 79.

${ }^{34}$ Nottingham Evening Post, 30 March 1908.

${ }^{35}$ Mellors, Gardens, p. 62; RBN, IX, 379.

${ }^{36}$ Ken Brand, An Introduction to Mapperley Park ( $2^{\text {nd }}$ edn., Nottingham: Nottingham Civic Society, 1996). 
The other major park development prior to 1914 was on the Trent Embankment to the south of the city centre. It ran along the north side of the River Trent from Trent Bridge to Wilford. Strictly speaking this was three interlinked parks. The Embankment was formed in 1901 when 28 acres along the river bank were given by the trustees of H.R. Clifton of Clifton Hall. It followed the installation of a flood prevention scheme (1898) designed to stop the river flooding across the low lying meadow land. The scheme cost $£ 58,409$, and the park opened in 1901. The second part was the Meadows Recreation ground, an area of 23 acres consisting of a bowling green opened in 1909, a cricket ground with a pavilion, 17 match wickets and 16 practice wickets, four football grounds and a children's playground. This opened in $1906 .{ }^{37}$ The third part dates from the 1920s.

Coupled with middle class ideas about physical fitness, and the role of churches and chapels in promoting active sport, the results by the end of the Victorian era were impressive. It helped that parks raised the value of adjacent land, and were well patronised when free bandstand entertainment was on offer. ${ }^{38}$ The major emphasis was on bowling greens and children's play areas, hence the acquisition of some quite small green spaces such as Millstone Lane, purchased in $1858,{ }^{39}$ St Michael's recreation ground in $1860,{ }^{40}$ and Nether Trent Close in $1876 .{ }^{41}$

${ }^{37}$ RBN, IX, 380, 396, 409; Mellors, Gardens, p. 69; Heritage England List Entry number 1001506. For the third part of the Embankment scheme see below.

\footnotetext{
${ }^{38}$ Metcalf, 'The idea of a Park', 20.

${ }^{39}$ RBN IX, 133.

${ }^{40} R B N$ IX, 146, 256, 262.

${ }^{41} R B N$ IX, 250.
} 


\section{Public Parks in the Inter-War Years}

Park creation stopped during the First World War, although parks were widely used for military training and patriotic events designed to keep up morale. The latter included the Notts Patriotic Fair in 1917 when thousands of schoolchildren were assembled on Nottingham's Forest recreation ground. Military parades, in and out of wartime, also took place on the Forest. $^{42}$

After the war urban health issues came back on to the political agenda, particularly in terms of the fitness or lack of it of the British working population. Parks increasingly became a political issue, with the agenda driven by Whitehall, local authorities, and private philanthropists. Local authorities in particular were faced with a combination of government directives in relation to playing fields, and their own commitment to the provision of green spaces in conjunction with public housing programmes.

Although the post-1918 development focus was primarily on housing provision, this was itself linked to the creation of parks and recreation grounds. Nottingham Corporation created several parks in the aftermath of the First World War, together with recreation grounds, in areas where they were responsible for new council housing estates. These included the Valley Road recreation ground (opened 29 April 1922) of 14 acres, which was created as part of the (Valley Road) outer ring road scheme: 'men out of employment being engaged for the purpose, and the road formation being greatly

\footnotetext{
${ }^{42} \mathrm{H}$. Gill, A Guide to Old Nottingham. Compiled for the Patriotic Fair, May 28th and 29th,
} 1917 (Nottingham: Cooke \& Vowles, 1917); Nottinghamshire Archives (NA) CA CM/61/1, Public Walks Committee 8 June 1876. 
raised, the land on the north thereof was made into playing grounds. There are eight hard tennis courts, 15 grass courts, two bowling greens, one 16 hole putting course, two cricket pitches, and two hockey grounds.' 43

Cinderhill (7 acres) cost $£ 5,000$, and was a joint enterprise with the Miners’ Welfare Committee of Babbington Colliery, which contributed $£ 1,500$. The land, just over 7 acres, was purchased from the Duke of Newcastle and was 'the only land available in the district suitable for a public park and recreation ground, which are greatly needed'. It included a bowling green, 3 hard tennis courts, a grass court, and football ground, children's playground and a small pavilion. ${ }^{44}$ The plans were drawn by the borough surveyor Wallis Gordon, and the set-up costs were $£ 2,900 .{ }^{45}$ As in other cases, this was a park designed simply to fit the space available, with relatively little planning or financial strategy.

Council estate inter-war developments were accompanied by green spaces. A good example is Melbourne Park, a 22-acre public space in Aspley, one of the major areas of housing development. This was originally announced in 1934 as Nottingham Passenger Transport Department's New Ground, complete with a pavilion, and facilities for bowls, tennis and cricket and football. By the time it opened in 1936 it was known as the Melbourne Road Recreation Ground, and it had facilities for cricket and football as well as a small changing room. It was a surprisingly large space given that one of the problems for the corporation in these years was to find land for housing, let alone green spaces. Initially the Corporation used land from within its existing (1877) boundaries.

\footnotetext{
${ }^{43}$ Mellors, Gardens, p. 82

${ }^{44}$ Mellors, Gardens, p. 79; Nottingham City Council, Reports to Council, 1923-4, 511.

${ }^{45}$ Nottingham City Council, Reports to Council, 1923-4, 45, 97.
} 
To supplement its resources, in 1920 the corporation applied for a major boundary extension to take over parishes in the surrounding area. After a public enquiry, this was refused. Consequently the corporation had to buy development land in neighbouring parishes, but it could not enjoy the fruits of the local rates from the houses it funded. The rates were paid to the county council, and a boundary extension was achieved only in $1933 .{ }^{46}$

In the meantime, the corporation had no practical alternative but to purchase land in surrounding parishes on which to layout new estates with accompanying green spaces. A case in point was the Lenton Abbey estate, west of the city and straddling the boundary between the parish of Lenton, within the city boundary, and the parish of Beeston, outside the city boundary. This was a gentleman's estate, not unlike Bulwell Hall and Vernon Park. At Lenton Abbey the house had been built for a businessman, James Green, in 1798-1800, and erroneously named 'Abbey' since it was nowhere near the site of the medieval monastic property. ${ }^{47}$ The City Council bought the house in 1925 with its surrounding 86 acres. The land was intended from the outset to be developed for working class council housing, but one acre was sold to the Church of England for a church (St Barnabas, Lenton Abbey), and four acres of land on the corner of Derby

${ }^{46}$ John Beckett, 'Frustrated Ambition: the Nottingham Boundary Extension of 1933', Transactions of the Thoroton Society, 105 (2001), 171-84.

${ }^{47}$ The sale catalogue of 1976 specifically and erroneously claimed that the house sat on 'the spot' where the Priory was built: University of Nottingham, Department of Manuscripts and Special Collections (UNMASC), Not 4P.D64.ABB. 
Road and Woodside Road were laid out as a public park, which included a football pitch. $^{48}$

Recreation grounds were opened to serve each of the new communities. A miniature park was opened at Bulwell in June 1931 by the Lord Mayor of Nottingham, 'the occasion being marked by appropriate civic ceremonial that was witnessed by a numerous assembly of citizens'. Councillor E.A. Braddock, one of Bulwell's representative on Nottingham City Council had suggested to the Public Parks Committee that an unsightly area of waste known as The Bog could usefully be converted into something rather pleasanter. The design was by City Engineer T. Wallis Gordon, and the land involved was two acres. The youngsters of Bulwell could 'make merry on a chute, a jumble climber, and a joy wheel'. Older folk could rendezvous on lawns and paths, and admire the oval lake. ${ }^{49}$ Bulwell Bogs is still there and open MayAugust each year.

In March 1935 Councillor W. Hooley, chairman of the Parks Committee of Nottingham Corporation, officially opened the new recreation ground on the Colwick side of the river at Trent Lane. It was three acres in extent and included a bowling green, with a small pavilion, a children's playground, with swings and a shelter. Hooley, in declaring the playground open, commentated that in his view 'it was the duty

\footnotetext{
${ }^{48}$ Report of Estates Committee, p. 39; Reports to Council, 1924-5, 499; 1925-6, 733.

${ }^{49}$ Nottingham Journal, 20 June 1931.
} 
of every council to provide playing grounds for children, and so keep them off the street' 50

These parks set a trend locally, but at a national level Nottingham's response to the first major post-1918 initiative came with its reaction to the formation in 1925 of the National Playing Fields Association. King George V personally headed up an appeal to lords lieutenants to form branches of the Association in their counties. A gathering held in the Royal Albert Hall on 8 July 1925 resolved

that this meeting, recognising the vital importance of playing fields to the physical, moral and mental welfare of the youth of the country, deplores the widespread and increasing shortage of recreation grounds and urges all Local Authorities, Sports Governing Bodies, Societies and members of the public interested in the matter to cooperate with the National Playing Fields Association in order that, by their united efforts, the deficiency may be met. ${ }^{51}$

The background to these claims was the war. The Victorians had wanted the working man to take part in structured, park-based games, and after the First World War leading military figures called for the government to provide funds for the purchase of open spaces for vigorous exercise and team pursuits. An 'Open Spaces Standard' was proposed, of 5 acres per thousand head of population, and four of the five acres were to be for physical recreation leaving only one for ornamental gardens. These guidelines

\footnotetext{
${ }^{50}$ Nottingham Evening Post, 19 March 1935; Nottingham City Council, Reports to Council, 1919-20, 171; 1923-4, 511.

${ }^{51}$ Seeley, Outdoor Recreation, p. 96
} 
were never implemented, but they gave a strong lead when it came to laying out new parks. $^{52}$

The link to King George V can still be seen today in the number of playing fields around the country dedicated to his memory. ${ }^{53}$ In Nottingham they included parks in the suburbs of Aspley and Carlton, the latter opened in May 1939 on the site of an old brick quarry and dry ash refuse tip. The new Recreation ground included three hard tennis courts, a bowling green, a football pitch and a hockey pitch. A pavilion was provided with dressing room accommodation, and the corporation received grants from the Playing Fields Association totalling $£ 250 .{ }^{54} \mathrm{~A}$ decade later, and in the same area of Nottingham, Councillor T. Roper officially opened a new recreation ground at Blue Bell Hill. $^{55}$

Nationwide by 1933 1,200 new playing fields covering 4,040 hectares had been made available for public use through the scheme. The cultural context reflected the growing importance of public spaces, notably playing fields, for healthy exercise. The Nottingham Parks Committee recalled in the 1920s that the Arboretum had been 'planned purely as an ornamental park', in the $1850 \mathrm{~s}$, and that 'unlike any other in Nottingham, [it] has been preserved from the encroachment of organised games'. It was, the writer claimed, suitable for 'the quieter forms of recreation' ${ }^{56}$ By contrast,

\footnotetext{
${ }^{52}$ Elborough, Walk in the Park, pp. 219-20.

${ }^{53}$ Seeley, Outdoor, pp. 96-7; Elborough, Walk in the Park, pp. 220-3.

${ }^{54}$ Nottingham Evening Post, 1 May 1939.

${ }^{55}$ Nottingham Evening Post, 11 May 1949.

${ }^{56}$ Nottingham City Council, Parks Report 1938, 999.
} 
organized games were linked with physical activity and outdoor pursuits more generally including rambling and hiking, rock-climbing, cycling and swimming. ${ }^{57}$

Subsequently the Physical Training and Recreation Act (1937) made available almost $£ 1 \mathrm{~m}$ to local authorities for the provision of sporting facilities. Parks were no longer viewed purely as a way of improving the leisure habits of the working class adult population; rather, they were seen as providing leisure facilities for all members of the community, irrespective of age or class. ${ }^{58}$ This marked a new era in the municipal provision of playing fields, gymnasia, swimming baths and lidos, holiday camps and camp sites, all far removed from the public walks and pleasure grounds of Victorian times. ${ }^{59}$ Municipal parks were designed with sports pitches, gardens and boating lakes, play grounds were provided for children, and provision was made for middle class activities including tennis and golf. The intention was to achieve a better standard of physical development in adults by providing them with opportunities for recreation. In addition, bowling greens were ubiquitous. ${ }^{60}$

Nottingham Corporation was aware that the city had an acute shortage of playing spaces, and the Education Committee claimed to be taking steps to secure as many playing fields as possible for use by schoolchildren. ${ }^{61}$ The National Playing Fields

${ }^{57}$ David Lambert, Jubilee-ation! A History of Royal Jubilees in Public Parks (Swindon: English Heritage, 2012), pp. 21-2

${ }^{58}$ Clark, Cambridge Urban History, II, p. 293.

${ }^{59}$ Jones, ‘State Intervention', 166.

${ }^{60}$ Clark, Cambridge Urban History, II, p. 293.

${ }^{61}$ David Pomfret, 'The city of evil and the great outdoors: the modern health movement and the urban young, 1918-40', Urban History, 28 (2001), 419. 
Association received a Royal Charter in 1932, when it defined a playing field as 'any open space used for the purpose of outdoor games, sports and pastimes' ${ }^{62}$ It also encouraged municipal authorities to take the lead. Nottingham Corporation had taken many initiatives since the Victorian era, but in the 1920s it acquired five large parks from private owners: Woodthorpe Grange, the Embankment, Highfields, Wollaton Park, and Newstead Abbey Park. ${ }^{63}$

Woodthorpe Grange Park, north of Nottingham city centre, was in the newly developing suburb of Woodthorpe. ${ }^{64}$ The 40 -acre park was originally a farm. It was purchased in the 1870s by Henry Ashwell, a master bleacher, dyer and finisher with a business in Basford. He turned it into a private estate and built a house, Woodthorpe Grange, in 1874 . The property passed through several hands until it was acquired by Alderman J.C. Small of Nottingham City Council. He sold it to the city council in 1921 for $£ 15,000$ to become a public park. Of this sum, Sir Jesse Boot, the pharmaceuticals entrepreneur, provided $£ 10,000$. Woodthorpe Park opened to the public on 1 June $1922 . .^{65}$

Two parts of the River Trent Embankment were already owned by the corporation in 1914. They acquired the third part, initially known as New Park, in the

${ }^{62}<$ http://www.fieldsintrust.org $>$ [accessed 30 April 2019].

${ }^{63}$ Layton-Jones, Public Park Funding, 23-5 on the question of transference from private owners to local authorities.

${ }^{64}$ Nottingham Local Studies Library (NLSL), L98; Duncan Gray, Nottingham Through 500 Years: a History of Town Government (Nottingham: Nottingham City Council, 1960), pp. 243-4

${ }^{65}$ NLSL L98; Gray, Nottingham, pp. 243-4. 
1920s. This 36.5 acre estate was acquired by Sir Jesse Boot from the Clifton family of Clifton Hall, and turned into a public park: 'in addition to all the usual accessories of parks - trees, shrubs, flowers, lake etc. [it] will have provision for cricket, football, tennis, hockey etc., and will form a delightful resort, readily accessible from the Trent Bridge trams'. Part of the land was turned into memorial gardens. The city's war memorial arch was built on the site after Boot gave it the land to the city. ${ }^{66}$ The arch itself was funded by a public subscription. The foundation stone was laid by the Prince of Wales on 1 August 1923, and the memorial was dedicated on 11 November 1927. Boot presented the rest of the land, now known as the Meadows Recreation Ground to the city, 'to be preserved for ever as an open space for the benefit of the citizens' ${ }^{67}$ It was to be devoted to the provision of sports grounds.

Highfields is today recognised as two adjoining parks: Highfields, owned by the City Council, and University Park, home to the University of Nottingham. It was a further gift to the city by Sir Jesse Boot, who purchased the Highfields estate in 1919. It consisted of 151 acres, and one of a number of small country houses (as with Vernon House) that ringed the city by this time. Boot's motives for acquiring the property have never been entirely clear, but from the point in July 1920 when he sold the Boots Company he became committed to the idea of turning Highfields into a public park. The recreational area spread across the grassy banks sweeping up toward Highfield House on the northern side of the lake. This area included three bowling greens, two putting

\footnotetext{
${ }^{66}$ NA, M 12,198.

${ }^{67}$ NA, CA/CM/11/1, Trust Minute Book, pp. 18, 23 July 1922; John Beckett and Ken Brand, 'City and County War Memorials', Nottingham Civic Society Newsletter, 155 (September, 1914), 11-18.
} 
greens, and a dancing green which was an early example of a public park providing space for the post-First World War dancing craze. ${ }^{68}$ A pamphlet produced on behalf of Boot suggested that the lawn would 'provide healthy amusement', and added that 'the quiet bird sanctuaries will please the lover of bird and animal life' ${ }^{69}$ All were laid out to the highest standard: as Boot wrote in 1925:

Our [bowling] greens are far superior and above the average, no expense having been spared in making them the best possible. All the top soil has been removed and properly levelled and a bed of ashes laid as a foundation to eliminate the damaging effect of worms, and the turfing done in the best possible manner with turf from Cumberland which is very expensive but recognised as the finest material for the purpose. ${ }^{70}$

A children's playground was laid out and, as at Woodthorpe Park, there was a paddling pool, commemorated today only in the name of an adjoining bus stop. ${ }^{71}$

Boot made one significant change to his Highfields scheme. In 1921 he decided to split the park into two. Thirty acres on the northern side of the lake, together with Highfields House, were earmarked for new buildings for the University College. Boot gave the land and house, and also funded the major new building (known today as the

${ }^{68}$ Elborough, Walk in the Park, p. 225.

${ }^{69}$ NLSL, University Park Boulevard and Playing Fields. Much of this pamphlet was reproduced in a long 'puff' on behalf of the project in the Nottingham Evening Post, 3 July 1924. The pamphlet quoted with approval the positive views of one of the leading town planners of the post war years, Professor Stanley Adshead: Oxford DNB, 30, 344.

${ }^{70}$ UNMASC, 911/19, Sir Jesse Boot to J.E. Shimeld, 4 July 1925.

${ }^{71}$ Nottingham Evening Post, 3 July 1924; Elborough, Walk in the Park, p. 225; NLSL University Park Boulevard and Playing Fields. 
Trent Building) and several other properties including halls of residence. University Park remains a separate park, but it is open to the public. ${ }^{72}$ Both Highfields and Woodthorpe Park included small country houses, which were converted for the use of the city council (Woodthorpe) and the University College (Highfields). ${ }^{73}$

The fourth major park acquired in the 1920s was Wollaton Park, with its magnificent Elizabethan prodigy house designed by Robert Smythson, and built by the Willoughby family in the sixteenth century. It was described by its owner, Lord Middleton, as being 'too near the smoke and busy activity of a large manufacturing town'. It sat, in fact, a couple of miles west of Nottingham city centre, but the town was gradually surrounding it: as Middleton commented: 'For this splendid house is now only removed from the borough by a narrow slip of country, and from its topmost places you may almost see what is going on in the heart of the town. ${ }^{74}$

Nottingham Corporation had been interested in acquiring Wollaton Park since the 1880 s. Their opportunity arrived when the Willoughbys were financially crippled by two sets of death duties in the early 1920s. Wollaton fell victim to the loss of interest in country houses by businessmen. Although Boot, put in an offer, he did so because he considered Wollaton to be a possible new site for Nottingham's University College

${ }^{72}$ Nottingham City Council, Reports to Council, 1932 part 2, 652, which includes a plan showing which part is the public park and which is the University Park.

${ }^{73}$ NLSL L98; Gray, Nottingham, pp. 243-4; UNMASC, Clifton Papers, CL 2/A16, fo. 149; NA, M.12,918; Beckett and Brand, 'City and County War Memorials', 11-18; Mellors, Gardens, p. 69; NLSL, University Park Boulevard and Playing Fields (June, 1924).

${ }^{74}$ L. Jacks, The Great Country Houses of Nottinghamshire (Nottingham: Bradshaw, 1881), pp. $179-80$ 
rather than as a great house for his own use. The Willoughbys preferred to sell to Nottingham Corporation, and the price agreed in 1925 was $£ 200,000 .^{75}$

This rather cosy arrangement might seem strange, but Peter Mandler has argued that during the inter-war years there was not much demand for great houses. Local authorities such as Nottingham Corporation needed the land in order to implement government housing policies. Even then, a mansion like Wollaton was an encumbrance. A survey of 1928 found that 20 per cent of local authority museums were housed in former country mansions, especially in the northern industrial towns. ${ }^{76}$ This was, in fact, the fate of many a redundant great house on the edge of an expanding twentieth century town or city. No one could think of anything else to do with it, so Wollaton was converted to house the city's natural history museum. ${ }^{77}$ At least it was convertible: other great houses in the area fell before the bulldozer, among them Clumber and Nuthall Temple. ${ }^{78}$

Having acquired Wollaton Park, the corporation divided it into several different usages. Part of the land was converted into a golf course, 300-acres were developed for housing and a new outer ring road for Nottingham, and the rest was turned into a 500acre public park which opened on 22 May 1926. These proportions were no surprise:

${ }^{75}$ Nottingham Evening Post, 26 May 1926; John Beckett, 'Contesting the Urban Fringe:

Nottingham City Council, Wollaton Hall and Broxtowe Hall, 1924-37', Transactions of the Thoroton Society, 108 (2004), 159-72.

${ }^{76}$ Peter Mandler, The Fall and Rise of the Stately Home (New Haven \& London, Yale University Press, 1997), pp, 227-58.

${ }^{77}$ Nottingham City Council, Reports to Council 1925-6, 529.

${ }^{78}$ Mandler, Fall and Rise, pp. 242, 255-7. 
'the cities', Mandler has suggested, 'flowed out into the country'. The number of houses increased by 30 per cent during the interwar years but the population rose by only 10 percent. ${ }^{79}$ But if part of Wollaton Park disappeared under bricks and mortar, the Nottingham Evening Post pointed to a particular benefit to be derived from the new arrangement: for the first time local people were allowed to 'wander in a park on which their forebears have gazed longingly for three centuries' ${ }^{80}$

Newstead Abbey, was the ancestral home of the poet, Lord Byron. The property came up for sale in the 1920s when part of the house and several acres of the grounds were acquired by Sir Julien Cahn, a local furniture magnate. He in turn gave it to the city in 1931 - after the National Trust had turned it down - which subsequently purchased land around the house, and also bought back the three parts of the house, not including the historic rooms dedicated to the memory of Byron, which had been sold to private tenants. Part of the funding came from the sale of plots of land in the wooded area of the grounds nearest to Mansfield Road. These were developed for high quality housing. The house itself was kept open to the public, but the property was too far north of the town to be incorporated into the public housing programme. It was converted into a corporation-owned public park dedicated (as at Wollaton) to family outings rather than to sport and physical exertion. ${ }^{81}$

\footnotetext{
${ }^{79}$ Mandler, Fall and Rise, p. 228.

${ }^{80}$ Nottingham Evening Post, 26 May 1926; Beckett, 'Contesting the Urban Fringe', 159-72.

${ }^{81}$ John Beckett, 'Twentieth Century Postscript: From Private to Public Ownership', in Newstead Abbey: a Nottinghamshire Country House: its owners and architectural history, 1540-1931 ed. by Rosalys Coope and Pete Smith (Thoroton Society Record Series, volume $48,2014), 165-8$.
} 
Nottingham corporation could not simply snap its fingers and expect landowners to sell up at favourable rates. Some estates close to the city have remained in private hands, such as Colwick Hall and Bestwood Lodge (both now hotels). Others were too far from the centre of the town to warrant the transport infrastructure investment required for people to reach them, at least before the era of mass car ownership from the 1960s.

\section{Across the County}

The main thrust of this article so far has been on Nottingham, but it should not be thought to be unusual: parks and recreation grounds were laid out in almost all the smaller towns of the surrounding county. A new park opened in Hucknall in July 1922, a gift from the Duke and Duchess of Portland, and the Marquess of Titchfield (their eldest son and heir). The 11-acre site had been presented seven or eight years previously but the war had interrupted its development. It had facilities for tennis and bowls and, in the words of the chairman of the local council, the park added 'to the opportunities for recreation of the inhabitants' ${ }^{82}$

Beeston, on the west side of the city, has several parks, mainly gifted to the local authority by the Pearson family, owners of the Beeston Boiler Company. Dovecote Lane Park, opened in 1907, was part funded by the Pearsons and part by the local authority. Henry Pearson, the driving force, also gave the land, insisted that the authority should make a bye-law prohibiting 'any person over the age of 16 years from playing any games thereon' ${ }^{83}$ A second recreation ground in Beeston, this time on

\footnotetext{
${ }^{82}$ Nottingham Journal, 10 July 1922.

${ }^{83}$ Nottingham Evening Post, 8 July 1908, p. 7.
} 
Broadgate, was a philanthropic gift from Sir Louis Pearson, chairman of the Beeston Boiler Company (and younger brother of Henry Pearson). This was opened by the Duke of Portland in 1923. He planted a ceremonial oak on the occasion despite pouring rain. ${ }^{84}$ Bramcote's King George V playing field opened in 1940 was the gift of yet another of the Pearson family, in this case Colonel Noel Pearson. ${ }^{85}$ Beeston, Bramcote, and adjoining Chilwell today have fourteen parks of greater or lesser size.

A recreation ground was opened at Burton Joyce, east of Nottingham, in 1925 as the result of a gift from a local man, Mr H.W. Roberts. It was 1.75 acres, and was intended to be a children's playground. ${ }^{86}$ The Radcliffe on Trent Memorial Park was opened in October $1927,{ }^{87}$ the Worksop Playing Field in $1935,{ }^{88}$ and Mansfield's first recreation ground in 1936 . This 6.5 acre recreation ground cost $£ 4,000$, and included a bowling green, two hard tennis courts, space for two football pitches and a small pavilion for the use of players as well as a shelter for children. Councillor Davey, Chairman of the Parks Committee, opening the new facility, described it as 'more or less a "seaside" place for the children.... There are hundreds of little children that can't afford to go to the sea and they will have to be satisfied with paddling in the water at Mansfield'. Here, as at other venues, the new park was opened with pomp and

\footnotetext{
${ }^{84}$ Beeston and Stapleford Official Guide (1962), p. 72; Mellors, Gardens, p. 102

${ }^{85}$ Nottingham Evening Post, 27 May 1936; 29 March 1940.

${ }^{86}$ Nottingham Journal, 25 May 1925.

${ }^{87}$ Nottingham Journal, 17 Oct 1927.

${ }^{88}$ Nottingham Journal, 3 July 1925.
} 
circumstance, speeches and presentations - but none of the children who were going to enjoy paddling seem to have been asked to attend. ${ }^{89}$

If there is a pattern here, it was replicated across the country. Within the Midlands new parks and arboreta were opened on a regular basis from the 1840s onwards. Derby arboretum (1840) was immensely popular. In 1847 the annual festival drew 16,000 people, many arriving by train from Nottingham, Leicester, Birmingham and Sheffield. A recreation ground was also provided in the town by Michael Bass, another of Derby's entrepreneurs. This followed a petition to the council in 1864 following a public meeting, and it opened in $1867 . .^{90}$ Leicester Corporation set aside a small part of their land in the South Fields 'as a place of amusement for the people' intended for games and sports, in other words a recreation ground rather than a park. Leicester's racecourse was renamed Victoria Park in 1866 yet by the end of that year the Leicester Journal was complaining that there was no public park or garden in Leicester. Abbey Park (1882) was the real first public park in Leicester and it was opened with suitable pomp and ceremony by the Prince and Princess of Wales. In 1871 Boston Corporation provided the first People's Park in Lincolnshire, a 33.5 acre site with pleasant walks and a bandstand. The Bishop of Lincoln, Dr Christopher Wordsworth, opened the 13 acre Arboretum on the eastern edge of Lincoln in 1872, and

\footnotetext{
${ }^{89}$ Nottingham Journal, 27 May 1936.

$90<$ https://historicengland.org.uk/listing/the-list/list-entry/1000677 [accessed 30 April 2019]; <https://www.inderby.org.uk/parks/derbys-parks-and-open-spaces/bass-

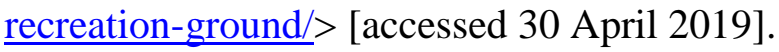


in 1883 a People's Park was opened in Grimsby, with excursions from Boston, Sheffield, Bradford and Doncaster. ${ }^{91}$

In the twentieth century Allestree Park was purchased by Derby corporation after the Second World War and used partly for housing, partly as a golf course, and partly as a nature reserve. St Chads parish, in Derby, promoted a recreation ground in 1925. Sir Richard Luce, M.P. speaking at the opening ceremony noted that sport was good for health and also for promoting 'the spirit of good comradeship and cooperation'. ${ }^{92}$ Grantham's Dysart Park was opened in July 1927 by the town mayor. It ran to seven acres, six given by Dysart and the other bought by the town council. It included a bandstand, football, cricket and other games areas, a paddling pool, bowling greens, tennis courts and a swimming baths. Following the opening 'the second annual Grantham Swimming Club aquatic sports and gala took place', and included races for both men and women. ${ }^{93}$ At Burton on Trent, the Duke of Devonshire opened a new recreation ground in June 1930. It was 10.5 acres and was laid out for tennis courts, cricket pitches, a bowling green and a putting green. ${ }^{94}$

In many cases the parks were laid out on what had previously been private land. What happened at Wollaton, for example, was paralleled elsewhere because many country houses threatened by suburban development were acquired by local authorities to supplement their post-First World War housing policies. Mostly the local authority wanted the land, usually with development in mind. The house could be an unwanted

\footnotetext{
${ }^{91}$ Metcalf, 'The idea of a Park'.

${ }^{92}$ Nottingham Journal, 8 June 1925.

${ }^{93}$ Nottingham Journal, 29 July 1927.

${ }^{94}$ Nottingham Journal, 26 June 1930.
} 
encumbrance. ${ }^{95}$ In some cases the house was reused, either as part of the recreation activities (such as a pavilion), and in other cases they were demolished. There was no single outcome.

The role of local authorities and private philanthropists in park creation was significant in the inter-war years, but they were not alone. Most of the major companies established sporting facilities for their employees, notably in Nottingham Boots, ${ }^{96}$ John Player, whose sports ground just off Western Boulevard is now a David Lloyd Leisure Centre, ${ }^{97}$ and, slightly later was the opening in December 1926 of the Raleigh Cycle Company's sports' ground on Wollaton Road. The celebrity invited to officiate at the opening was Miss Nora Bancroft, who was playing the principal boy in the Theatre Royal's Christmas pantomime, 'Goldilocks'. Miss Bancroft kicked off a football match between teams representing 'the Old Works, in other words the cycle section of the Company's huge undertaking, and the New Works, where the motor cycles are manufactured'. The site was 13 acres and, when complete, included four football pitches, three cricket pitches, and 'a cinder cycle track which will be one of the finest to

95 Mandler, Fall and Rise of the Stately Home, p. 256.

${ }^{96}$ S. Phillips, "Fellowship in recreation, fellowship in ideals': sport, leisure and culture at Boots Pure Drug Company, Nottingham c.1883-1945', Midland History, 29 (2004), 107-123; S. Phillips, 'Industrial welfare, Recreation and Retailing at Boots Pure Drug Company, 18831945', Transactions of the Thoroton Society, 112 (2008), 221-35.

${ }^{97}$ D. O'Neill, 'John Player \& Sons: the heyday and decline of cigarette marketing', Transactions of the Thoroton Society, 119 (2015), 205-17. 
be found the Midlands. Three laps of the track are to cover a mile, and it will be seven yards wide' ${ }^{98}$

\section{Conclusion}

Public parks were part of the municipalisation of urban facilities in the course of the nineteenth and twentieth centuries. Initially the emphasis was on genteel promenading along public walks and through the Arboretum and cemeteries, and the older fashion for static entertainment was never lost. Horticultural shows were important from the beginning, and they continued to be so. In 1938 the Aspley Tenants Horticultural Society held its annual show on the park at Cinderhill, the St Ann's Rose Show was on the Coppice Road recreation ground, the United Aspley Garden Holders’ Association held theirs on Melbourne Park, and the Lenton and District Horticultural Society on University Park. ${ }^{99}$

Also static but popular were concerts on the bandstands during the summer months. In 1923-4 band performances took place on the Arboretum, the Forest, Woodthorpe Grange, Vernon Park, Bulwell Hall Park, and the Victoria Embankment. In 1938, band concerts were still taking place at all of these venues, together with University Park, Cinderhill, Lenton, and Queen's Drive. The parks' department report that 'special bands were provided on three occasions in the Arboretum, and the attendances were very satisfactory'. ${ }^{100}$ Sometimes restrictions were placed on

\footnotetext{
${ }^{98}$ Nottingham Evening Post, 24 December 1926.

${ }^{99}$ Nottingham City Council, Reports to Council 1938 part 2, 998.

${ }^{100}$ Nottingham City Council, Reports to Council 1938 part 2, 998.
} 
bandstands. Henry Pearson gave Dovecote Lane and presented the bandstand, on condition that its use was restricted to children under $14 .{ }^{101}$

These activities continued, but in the course of time there was a subtle shift in the way parks were used, particularly in relation to active recreation. At one level this was paddling pools, which were found in many of Nottingham's public parks, but at another it was the development of recreation grounds for sporting activities, notably football, with rugby and hockey for the winter months, and cricket, tennis and golf for the summer. This was 'sport for all' to use a later popular phrase, and it was about achieving physical fitness in the population via sporting activities, most of which were competitive and were played on outdoor facilities. Sir Jesse Boot, for example, promoted amenities for active outdoor sport (including football, cricket, swimming and tennis) but was far less interested in indoor activities, and resisted attempts by the University College to persuade him to fund a gymnasium. ${ }^{102}$

Sport continues to be played on parks, but it is expensive for the local authorities to upkeep football and cricket pitches, among others. There has been a need as well for parks to reflect the demands of their users, hence the increase in outdoor fitness areas as people take responsibility for their own health. Another victim of this change of habits has been the loss of the old welfare organisations linked to the major employers. ${ }^{103}$

\footnotetext{
${ }^{101}$ Mellors, Gardens, p. 102.

${ }^{102}$ UNMASC, UR 799/104, Shimeld to Boot, 13 September 1929; 106/1, Boot to Shimeld, 14 September 1929.

${ }^{103}$ Outdoor fitness areas can currently be found in 23 separate park and recreation grounds in and around Nottingham. Information courtesy of James Dymond.
} 
Fortunately the parks survive, even if the modern emphasis is on dog walking, child friendly play equipment, and bowling.

This paper does not tackle the period after the Second World War, but the important link between green spaces and new areas of housing has continued to be observed. Nottingham in 2020 had 128 parks and green spaces, and much has been achieved through a combination of public and private initiatives. In a survey conducted in 2017,32 of the 128 spaces within the city boundary were given the Green Flag Award by the environmental charity Keep Britain Tidy. Parks which win Green Flag status have to demonstrate the highest possible environmental standards, that they are well maintained and have good visitor facilities. ${ }^{104}$ Nottingham also does well at a national level with 15.3 per cent of its area being green space. It comes second only to Birmingham, with 15.6 per cent. By contrast Leeds with 6.6 per cent and Bristol with 6.8 per cent demonstrate the Corporation's success in terms of retaining its green spaces. ${ }^{105}$ In 201968 parks across Nottinghamshire were awarded Green Flag status. ${ }^{106}$

At times in the past, interest in parks has wavered, and concern has been expressed as to how safe they are to use, ${ }^{107}$ but in recent years the Big Lottery Fund with its commitment to reviving public parks, and working together with the Heritage Lottery Fund, has led to the availability of substantial sums of money for restoration programmes. Since 2006 nearly $£ 290$ m of National Lottery cash has been spent in reviving 126 historic green spaces across the country. The money has been invested,

\footnotetext{
${ }^{104}$ Nottingham Evening Post, 19 July 2017.

${ }^{105}$ Sunday Times, 9 July 2017.

${ }^{106}$ Nottingham Post, 17 July 2019

${ }^{107}$ Layton-Jones, Public Park Funding, 9
} 
according to the chairman of the Big Lottery Fund because green spaces are 'vital to the happiness and health of our communities', a sentiment which stretches back to the 1840s. ${ }^{108}$ Nottingham has also benefited from external grants, including $£ 870,000$ from the National Lottery Heritage Fund, and $£ 800,000$ from developer funds, both in 2019. ${ }^{109}$

The extent of green spaces has actually increased over time. Where, for example, heavily overcrowded areas of low quality working class houses have been swept away by post-1945 redevelopment the space made available had much lower density housing, and included green spaces of one size or another. This was true of, for example, the St Ann's, Meadows, and Hyson Green redevelopments of the 1960s and 1970s. Post-1945 developments all had green spaces. The vast Clifton estate, on which work started after the war, was provided with open and green spaces including Clifton Central Park and Clifton Playing Fields. ${ }^{110}$ A combination of private and public money, together with the wider demands of the housing programme between the end of the First World War and the introduction in 1982 of the Conservatives policy on the sale of council houses, has led to the ongoing creation of green spaces across our cities. ${ }^{111}$

\section{Acknowledgements}

\footnotetext{
${ }^{108}$ Big Lottery Press Release, 10 September 2015.

${ }^{109}$ Nottingham Post, 19 June, 6 August 2019.

$110<$ Documents/Downloads/Clifton\%20Central\%20Park\%20and\%20Playing\%20Fields.pdf> [accessed 30 April 2019]

${ }^{111}$ Nottingham Evening Post, 3 April 2018.
} 
I am grateful to Professor Paul Elliott and Dr Richard Gaunt for comments on an earlier draft of this paper, to two anonymous referees, and to Andrew Nicholson for drawing the maps. The underpinning research was conducted as part of the AHRC Connected Communities programme: ‘The Social World of Nottingham's Historic Green Spaces: a Community History project' (2013-14, AH/K0077/18/1; 2016 follow on project, AH/N006402/1). The author was Principal Investigator on this project.

\section{Disclosure statement}

No potential conflict of interest was reported by the author. 
Captions for images:

Fig 1. Nottingham's green spaces as laid out under the terms of the 1845 Enclosure Act.

[Should go near footnote 19 on p. 7 of the text]

Fig 2. Corporation Oaks. One of several green spaces made available after 1845 for promenading.

NTGM000006 Corporation Oaks

[Should go near footnote 19 on p. 7 of the text]

Fig 3. Nottingham and surrounding areas post-1870 green spaces

[Should go near footnote 28 on p. 9 of the text

Fig 4. Patriotic Fair, 1917, the Arboretum.

DCH 0504601

[Should go near footnote 42 p. 13]

Fig 5. Relaxing on The Forest. Note the Bandstand.

[Should go near footnote 38 p. 12]

IMGF 464 